\title{
Another Uranophile Sodium Hydroxycalix[8]arene-p-sulfonate: Its Acid Dissociation and Divalent Metal Ion Binding Properties
}

\author{
Miwako SonOdA*, Kenji HaYASHI**, Masashi NiSHIDA*, Daido IsHII* and Isao YoshIDA*† \\ * Department of Industrial Chemistry, Kumamoto Institute of Technology, \\ Ikeda, Kumamoto 860-0082, Japan \\ **Tzurumisoda Co., Suehiro, Tzurumi, Yokohama 230-0045, Japan
}

\begin{abstract}
Acid dissociation constants of the hydroxyl groups of sodium hydroxycalix[8]arene- $p$-sulfonate $\left(\mathbf{1}_{8}=\mathrm{Na}_{8} \mathrm{H}_{4} \mathrm{~L}\right)$ were measured by the $\mathrm{pH}$ titration method in an aqueous solution. The acid dissociation constants determined were as follows: $\mathrm{p} K_{\mathrm{a} 1}=3.73 \pm 0.05, \mathrm{p} K_{\mathrm{a} 2}=4.39 \pm 0.05, \mathrm{p} K_{\mathrm{a} 3}=8.07 \pm 0.02, \mathrm{p} K_{\mathrm{a} 4}=10.1 \pm 0.1$ under the conditions of $\mu=0.1$ with $\mathrm{KNO}_{3}$ and $25^{\circ} \mathrm{C}$. Furthermore, the complex formation reactions of $\mathbf{1}_{8}$ with some divalent metal ions such as $\mathrm{Mg}^{2+}, \mathrm{Ca}^{2+}, \mathrm{Mn}^{2+}, \mathrm{Co}^{2+}, \mathrm{Ni}^{2+}$, $\mathrm{Cu}^{2+}, \mathrm{Zn}^{2+}$, and $\mathrm{UO}_{2}{ }^{2+}\left(\mathrm{M}^{2+}\right)$ were investigated by the $\mathrm{pH}$ titration method in aqueous solutions and the stability constants of the complexes were evaluated. No complex formation was observed for $\mathrm{Cu}^{2+}$. The slight formation of complexes having a 1:1 molar ratio $\left(\mathrm{M}^{2+}: \mathbf{1}_{8}\right)$ was observed for all other divalent metal ions except for $\mathrm{UO}_{2}{ }^{2+}$. In contrast, $\mathrm{UO}_{2}{ }^{2+}$ formed a relatively stable 2:1 complex in addition to an unstable 1:1 complex. These results indicate that $\mathbf{1}_{8}$ is a highly selective metal ligand for $\mathrm{UO}_{2}{ }^{2+}$ among the various divalent metal ions.
\end{abstract}

Keywords Water soluble calix[8]arene, acid dissociation constant, divalent metal complex, stability constant, high uranophile

The development of a peculiar ligand which can selectively extract $\mathrm{UO}_{2}{ }^{2+}$ from seawater has attracted extensive attention from chemists for more than two decades because of its importance in relation to energy problems. As a possible unique solution for this problem, Shinkai et al. ${ }^{1}$ synthesized a macrocyclic ligand with a nearly coplanar arrangement of either five or six donating groups which can serve as a specific donating group for $\mathrm{UO}_{2}{ }^{2+}$ uptake. They examined the complexing ability of these groups with various divalent metal ions. They found that sodium hydroxycalix [5] arene- $p$ sulfonate, $\mathbf{1}_{5}$, sodium hydroxycalix[6]arene- $p$-sulfonate, $\mathbf{1}_{6}$, and their penta- or hexacarboxylated derivatives, $\mathbf{1}_{5} \mathrm{CH}_{2} \mathrm{COOH}$ and $\mathbf{1}_{6} \mathrm{CH}_{2} \mathrm{COOH}$ form 1:1 complexes with $\mathrm{UO}_{2}{ }^{2+}$ and that the complexes have remarkably large stability constants $\left(\log K_{\mathrm{UO} 2}=18.9-19.2\right)$ with high selectivity factors $\left(\log \left(K_{\mathrm{UO} 2} / K_{\mathrm{M} 2+}\right)=10-17\right)$ in water. ${ }^{1}$ Such high selectivity was attributed to the rigged skeleton of calix $[n]$ arenes ( $n=5$ and 6$)$ which can provide pre-organized penta- or hexacoordination geometry for the binding of $\mathrm{UO}_{2}{ }^{2+}$.

We investigated divalent metal ion binding properties of sodium hydroxycalix[8]arene- $p$-sulfonate, $\mathbf{1}_{8}$, which has eight donating groups on a more flexible macrocyclic skeleton than those of $\mathbf{1}_{5}$ and $\mathbf{1}_{6}$. We found that $\mathbf{1}_{8}$ forms a highly stable $1: 2\left(\mathbf{1}_{8}: \mathrm{UO}_{2}{ }^{2+}\right)$ complex with $\mathrm{UO}_{2}{ }^{2+}$, similar to that formed by $\mathbf{1}_{5}$ and $\mathbf{1}_{6}$ in stability. But extremely unstable 1:1 complexes were formed

\footnotetext{
$\doteqdot$ To whom correspondence should be addressed.
}

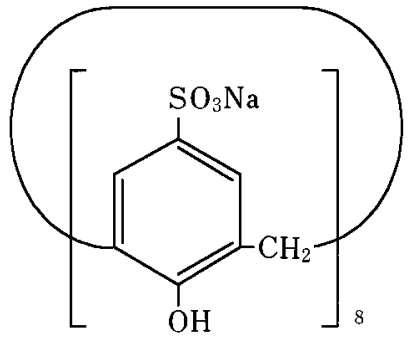

Scheme 1 Sodium hydroxycalix [8]arene-p-sulfonate, $\mathbf{1}_{8}$.

with other divalent metal ions such as $\mathrm{Ca}^{2+}$ and $\mathrm{Zn}^{2+}$, according to accurate analyses of $\mathrm{pH}$ titration curves. There was no complex formed with $\mathrm{Cu}^{2+}$. In the present paper, we report acid dissociation constants of $\mathbf{1}_{8}$, its complex formation reactions with some divalent metal ions including $\mathrm{UO}_{2}{ }^{2+}$ together with their stability constants, high selectivity factors for $\mathrm{UO}_{2}{ }^{2+}$ in divalent metal ions, and the finding that $\mathbf{1}_{8}$ is another uranophile which has highly selective reactivity for $\mathrm{UO}_{2}{ }^{2+}$.

\section{Experimental}

\section{Materials}

Hydroxycalix[8] arene- $p$-sulfonic acid sodium salts, $\mathbf{1}_{8}$ were obtained commercially from Sugai Kagaku Co.(Wakayama, Japan) and used after purification by recrystallization with water. Pure white crystals were 
obtained after performing recrystallization three times starting from the pale-yellow powder. The $\mathrm{pH}$ value of the aqueous mother solution was about 3 . The white solid product was dried at $60^{\circ} \mathrm{C}$ under reduced pressure for $24 \mathrm{~h}$, then used for titration studies.

\section{pH titration}

Procedures, instrumentation and methods for $\mathrm{pH}$ $\left(-\log \left[\mathrm{H}^{+}\right]\right)$measurement similar to those described in our previous paper $^{2}$ were used for the $\mathrm{pH}$ titrations. The sample solution containing $0.05-0.1 \mathrm{mmol}$ of $\mathbf{1}_{8}$ was titrated with $0.1 \mathrm{M}$ carbonate free potassium hydroxide in a $50 \mathrm{ml}$ water jacket cell in the presence and absence of metal ion at $25^{\circ} \mathrm{C}$ in a nitrogen stream. The ionic strength was adjusted to 0.1 with potassium nitrate. The $\mathrm{pH}$ of the sample solution was measured at every step of titration.

\section{Spectrophotometric titration}

Due to the difficulty in ascertaining which group of the multidentate ligand is deprotonated by the $\mathrm{pH}$ titration only, a spectrophotometric titration was carried out in the $0.1 \mathrm{M} \mathrm{KCl}$ solution simultaneously. The instrumentation used for spectrophotometric titration was basically similar to that for the $\mathrm{pH}$ titration. Using a micro tube pump, the sample solution in a reaction vessel was circulated at every step of titration through a small silicon tube into a Shimadzu SPD-6AV spectrophotometer equipped with a micro flow photocell. The micro flow cell was $1 \mathrm{~cm}$ in light-pass length and 8 $\mu \mathrm{l}$ in volume. The optical absorbance of the reaction mixture was measured at several wavelengths between $250 \mathrm{~nm}-290 \mathrm{~nm}$. At the same time, the $\mathrm{pH}$ of the reaction mixture was measured using a Horiba F-8AT $\mathrm{pH}$ meter. The same types of glass and reference electrodes were used in a similar way for $\mathrm{pH}$ titration.

\section{Results and Discussion}

\section{UV spectra of $\boldsymbol{1}_{8}$}

Prior to the titration studies, the sodium and sulfur contents of $\mathbf{1}_{8}$ were determined by an ICP-AES method in an aqueous solutions using a Seiko-densi SPS1200VR. Analytical results indicated that $\mathbf{1}_{8}$ has $1 \mathrm{~mol}$ of sodium per $1 \mathrm{~mol}$ of sulfur atoms. It was also found that no other metal cations, such as barium or potassium, nor anions such as chloride were present. This fact indicates that $\mathbf{1}_{8}$ is in the form of 8th sodium salts. Thus, it can be concluded that $\mathbf{1}_{8}$ has a maximum of 8 dissociable protons in the aqueous solution. If some of these are sulfonic protons, they would easily dissociate at relatively low $\mathrm{pH}$, while if some are phenol protons, they would not dissociate even at an extremely high $\mathrm{pH}$.

Due to the phenols, the UV absorption peak usually shifts to a longer wavelength side and the absorbances increase when a hydroxyphenol dissociates to form a phenolate ion by an increase in $\mathrm{pH}$. In contrast, the absorbance of the solution containing phenolate ion may decrease and the absorption peak may shift to the shorter wavelength side by an addition of acids.

Two absorption peaks were observed in the UV spectrum of $\mathbf{1}_{8}$ in water at 275 and $283 \mathrm{~nm}$. They moved to the longer wavelength side where the absorbance increased with an increase in $\mathrm{pH}$. At $\mathrm{pH}<2$, the absorbance is constant regardless of the change in $\mathrm{pH}$, as shown in Fig 1. Thus we can conclude that no acid dissociation of any hydroxyl proton takes place at $\mathrm{pH}<2$. This evidence indicates the presence of a phenol group and the absence of a phenolate ion. As a result, the presence of sodium sulfonates for all sulfonic groups in $\mathbf{1}_{8}$ is indicated, because no other metal ions were present. This means that all of the dissociable protons in $\mathbf{1}_{8}$ are from the phenol groups. This is supported by the fact that sodium hydroxycalix[4]arene- $p$ sulfonate, $\mathbf{1}_{4}$, which was obtained by recrystallization from water( $\mathrm{pH} c a .3)$, was also in a form of tetrahydroxytetrasodiumsulfonate. ${ }^{2}$

The results of the elemental analyses and IR spectra suggest the presence of water in $\mathbf{1}_{8}$. The presence of water is also reported elsewhere. ${ }^{3}$ The complete removal of water was difficult without the decomposition of $\mathbf{1}_{8}$. The presence of water does not interfere with the titration study in the aqueous system; thus the experiments were carried out using samples containing water.

\section{Titration curves of calixarenes}

The titration curve for $0.110 \mathrm{mmol}$ of $\mathbf{1}_{8}$ in a $40 \mathrm{ml}$ of aqueous solution is shown in Fig. 2. The number on the abscissa, $a$, indicates the molar ratio of $\mathrm{KOH}$ added to an amount of $\mathbf{1}_{8}$. The titration curve has a $\mathrm{pH}$ buffer region from $a=0$ to $a=4$, indicating an inflection at $a=2$

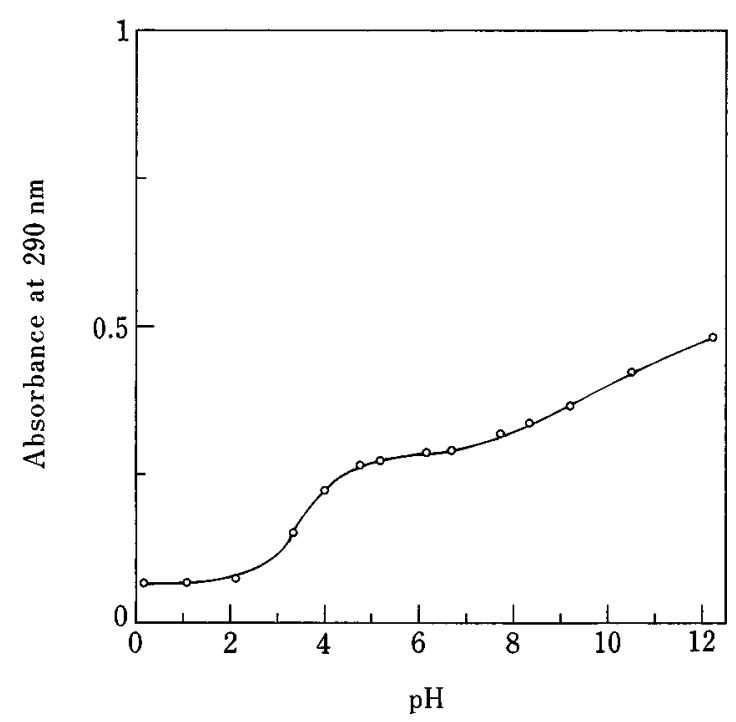

Fig. 1 Variation in absorbance due to the deprotonation of $\mathbf{1}_{8}$ at $283 \mathrm{~nm}$ as a function of $\mathrm{pH} . \mu=0.1$ with $\mathrm{KCl}$ at $2<\mathrm{pH}<12$, $\mathbf{1}_{8}=2.5 \times 10^{-5} \mathrm{M}$, initial volume of the sample solution=40 ml, light-pass length $=1 \mathrm{~cm}$. 


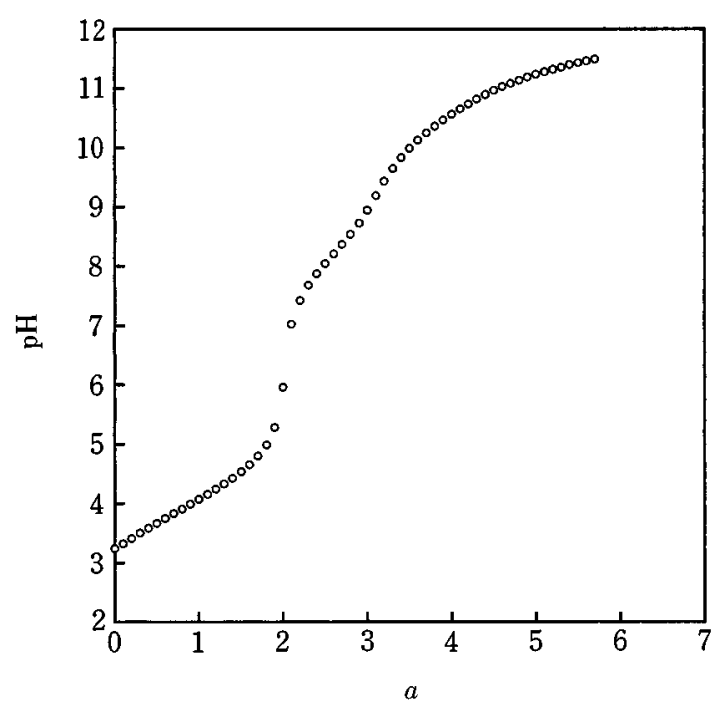

Fig. $2 \mathrm{pH}$ titration curve for $\mathbf{1}_{8}$ with $0.1 \mathrm{M} \mathrm{KOH}$ at $25^{\circ} \mathrm{C}$. $\left[\mathbf{1}_{8}\right]=2.76 \mathrm{mM}, \mu=0.1$ with $\mathrm{KNO}_{3}$, initial volume $=40 \mathrm{ml}$, $a=$ molar ratio of $\mathrm{KOH}$ added $/ \mathbf{1}_{8}$

and another small one at $a=3$. This indicates that $\mathbf{1}_{8}$ dissociates two protons up to $a=2$ in a weakly acidic solution of $\mathrm{pH}<6$, one of the remaining two protons up to $a=3$ at about $\mathrm{pH}=8$, and the other up to $a=4$ at about $\mathrm{pH}=10$.

\section{Acid dissociation constants}

Acid dissociation constants were computed using the titration data for various amounts of $\mathbf{1}_{8}$ using the computer program PKAS $;{ }^{4}$ the results are shown in Table 1. When the quantity of titratable protons in $\mathbf{1}_{8}$ is presumed to be 4 , the best agreement obtained for calculated $\mathrm{pH}$ values and those measured over all points of titrations gave the smallest $\sigma$ values $^{4}$, where $\sigma=\left(\sum W \cdot\left(\mathrm{pH}_{\mathrm{obs}}-\mathrm{pH}_{\mathrm{calc}}\right)^{2} / \sum W\right)^{1 / 2}, W=\left(\mathrm{pH}_{i+1}-\mathrm{pH}_{i-1}\right)^{-2}$ and $i$ is the number of titration points. The smaller the $\sigma$ value, the larger the degree of agreement between the calculated and measured $\mathrm{pH}$ values. From the resultant $\mathrm{p} K_{\mathrm{a}}$ values shown in Table 1, the mean values were calculated for each $\mathrm{p} K_{\mathrm{a}}$ and the acid dissociation constants of $\mathbf{1}_{8}$ were determined to be $\mathrm{p} K_{\mathrm{a} 1}=3.73 \pm 0.05$, $\mathrm{p} K_{\mathrm{a} 2}=4.39 \pm 0.05, \mathrm{p} K_{\mathrm{a} 3}=8.07 \pm 0.02$, and $\mathrm{p} K_{\mathrm{a} 4}=10.1 \pm 0.1$.

The sulfonate ion of $\mathbf{1}_{8}\left(\mathrm{H}_{4} \mathrm{~L}^{8-}\right)$ dissociates two protons in the acidic solution, while the third deprotonation can

Table 1 Acid dissociation constants, $\mathrm{p} K_{\mathrm{a} n}$, of hydroxyl groups in $\mathbf{1}_{8}$ at $25{ }^{\circ} \mathrm{C}$ and $\mu=0.1$ with $\mathrm{KNO}_{3}$

\begin{tabular}{lcccc}
\hline $\mathbf{1}_{8} / \mathrm{mmol}^{\mathrm{a}}$ & $\mathrm{p} K_{\mathrm{a} 1}$ & $\mathrm{p} K_{\mathrm{a} 2}$ & $\mathrm{p} K_{\mathrm{a} 3}$ & $\mathrm{p} K_{\mathrm{a} 4}$ \\
\hline 0.06481 & 3.67 & 4.46 & 8.09 & 10.1 \\
0.06530 & 3.68 & 4.37 & 8.08 & 10.2 \\
0.1104 & 3.77 & 4.33 & 8.05 & 10.1 \\
Mean & $3.73 \pm 0.05$ & $4.39 \pm 0.05$ & $8.07 \pm 0.02$ & $10.1 \pm 0.1$ \\
\hline
\end{tabular}

a. Initial volume $=40 \mathrm{ml}$.

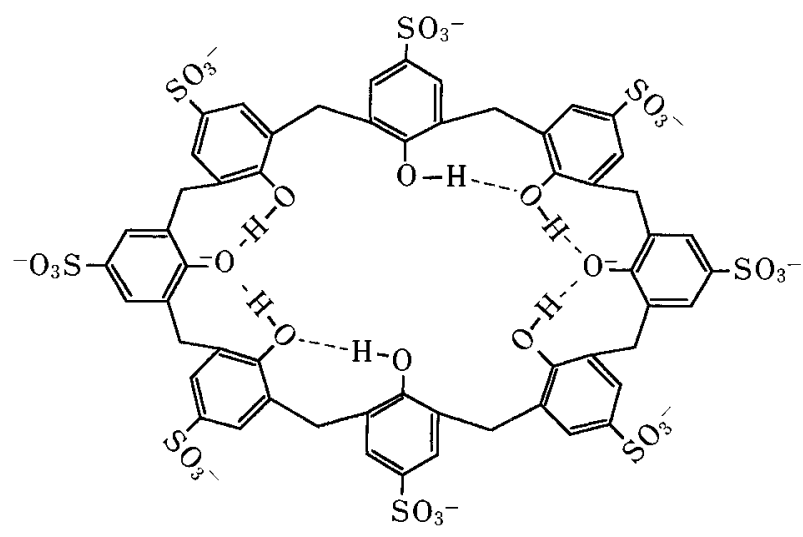

Scheme 2 Proposed intramolecular hydrogen bondings for $\mathrm{H}_{2} \mathrm{~L}^{10-}$ which appear similar to bis-deprotonated $\mathbf{1}_{4}$.

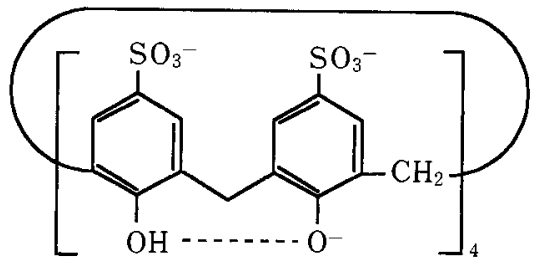

Scheme 3 Proposed intramolecular hydrogen bondings for $\mathrm{L}^{12-}$ in which 4 hydroxyl protons were dissociated alternately.

only take place in the alkaline solution. This fact suggests that ionic species $\mathrm{H}_{2} \mathrm{~L}^{10-}$ is considerably stabilized due to the formation of intramolecular hydrogen bonds in its macro cyclic ring, as shown in Scheme 2. This species seems similar to a biscalix[4]arene, bis-1 ${ }_{4}$, where $1 \mathrm{~mol}$ of $\mathbf{1}_{8}$ dissociates $2 \mathrm{~mol}$ of protons and forms a stable bis-tetramer. After the fourth deprotonation took place, no more deprotonation was observed in the higher alkaline solution. So we believe the neighboring phenol and phenoxide ions formed four couples of hydrogen bonds alternately, as indicated in Scheme 3 , and the ionic molecule also stabilized. Thus it can be concluded that $\mathbf{1}_{8}$ in an aqueous solution is a tetrabasic acid in the form of $\mathrm{Na}_{8} \mathrm{H}_{4} \mathrm{~L}$.

\section{Complex formation of $\mathbf{1}_{8}$ with divalent metal ions}

The formation of metal complex, $\mathrm{M}_{m} \mathrm{~L}_{l} \mathrm{H}_{h}$ and its stability constant, $\beta_{m l h}$ were determined using the computer program BEST ${ }^{4}$ from the analyses of the $\mathrm{pH}$ titration curves of $\mathbf{1}_{8}$ which were measured in the presence of divalent metal ions.

$$
\begin{aligned}
& m \mathrm{M}+l \mathrm{~L}+h \mathrm{H} \rightleftharpoons \mathrm{M}_{m} \mathrm{~L}_{l} \mathrm{H}_{h} \\
& \beta_{m l h}=\left[\mathrm{M}_{m} \mathrm{~L}_{l} \mathrm{H}_{h}\right] /[\mathrm{M}]^{m}[\mathrm{~L}]^{l}[\mathrm{H}]^{h}
\end{aligned}
$$

In Eqs. (1) and (2), the charges of metal ion, ligand and 
complex species are omitted in order to more simply express the equations.

\section{$\mathbf{1}_{8}-\mathrm{UO}_{2}{ }^{2+}$ complexes and their stability constants}

Some $\mathrm{pH}$ titration curves for $\mathbf{1}_{8}(R=\infty)$ and $\mathbf{1}_{8}-\mathrm{UO}_{2}{ }^{2+}$ mixtures $(R=2.1-0.53)$ are shown in Fig. 3, where $R$ is $\mathbf{1}_{8} / \mathrm{M}^{2+}$ in molar ratio. Compared to $\mathbf{1}_{8}$ alone, the presence of $\mathrm{UO}_{2}{ }^{2+}$ decreases $\mathrm{pH}$ values considerably in proportion to the amount of $\mathrm{UO}_{2}{ }^{2+}$ present, i.e., with decreasing $R$ values in the sample solution. Therefore, it is clear that $\mathbf{1}_{8}$ forms some complexes with $\mathrm{UO}_{2}{ }^{2+}$ by dissociating protons even in the acidic solution. From the inflection points of each titration curve, we were able to calculate the amount of hydrogen ions released from $1 \mathrm{~mol}$ of $\mathrm{UO}_{2}{ }^{2+}$, followed by complex formation with $\mathbf{1}_{8}$, and found it to be $3.5 \mathrm{mmol}$.

All pH titration data were analyzed by using the computer program BEST ${ }^{11}$ under the above presupposition

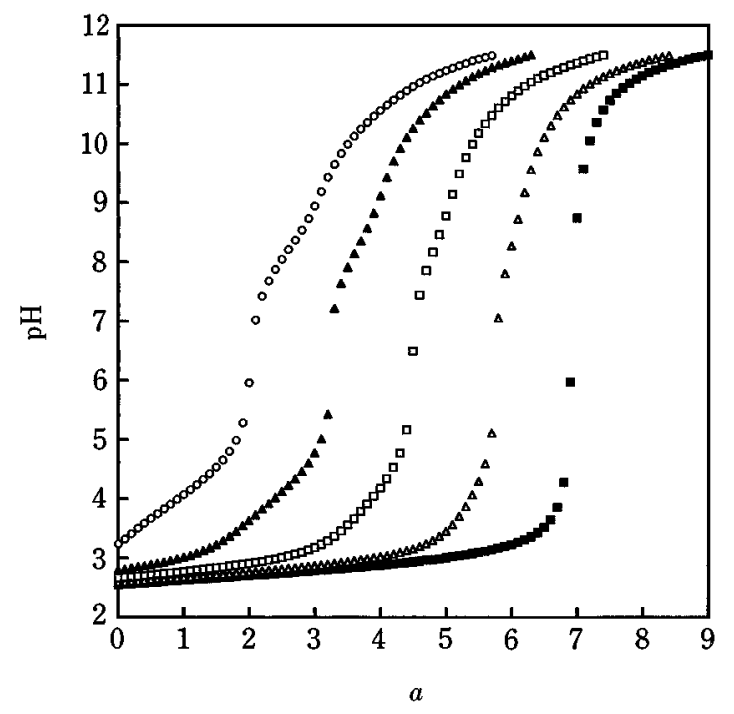

Fig. 3 pH titration curves for $\mathbf{1}_{8}(0, R=\infty)$ and $\mathbf{1}_{8}-\mathrm{UO}_{2}{ }^{2+}$ mixture solutions $(R: \triangle, 2.1 ; \square, 1.3 ; \triangle, 0.71 ; \square, 0.53)$ with $0.1 \mathrm{M}$ $\mathrm{KOH}$ at $25^{\circ} \mathrm{C}$. $\mu=0.1$ with $\mathrm{KNO}_{3}$. Initial volume of sample solution $=40 \mathrm{ml}$.

Table $2 \mathbf{1}_{8}-\mathrm{UO}_{2}{ }^{2+}$ species and their stability constants, log $\beta_{m l h}{ }^{\mathrm{a}}$ at $25^{\circ} \mathrm{C}$

\begin{tabular}{|c|c|c|c|c|}
\hline \multirow[t]{2}{*}{$R^{\mathrm{b}}$} & \multicolumn{2}{|c|}{$\begin{array}{l}\text { Amount of } \mathrm{UO}_{2}^{2+} \\
\text { and } \mathbf{1}_{8} / \mathrm{mmol}^{\mathrm{c}}\end{array}$} & \multicolumn{2}{|c|}{$\log \beta_{m l h}$} \\
\hline & $\mathrm{UO}_{2}{ }^{2+}$ & $\mathbf{1}_{8}$ & 112 & 21-3 \\
\hline 0.53 & 0.207 & 0.110 & 23.27 & 12.34 \\
\hline 0.71 & 0.155 & 0.110 & 22.97 & 12.31 \\
\hline 1.1 & 0.104 & 0.110 & 22.71 & 12.11 \\
\hline 1.3 & 0.0518 & 0.0648 & 22.11 & 12.19 \\
\hline 2.1 & 0.0518 & 0.110 & 22.56 & 11.71 \\
\hline Mean & & & $22.72 \pm 0.39$ & $12.13 \pm 0.23$ \\
\hline
\end{tabular}

a. $\mu=0.1$ with $\mathrm{KNO}_{3}$.

b. $R=$ molar ratio of $\mathbf{1}_{8}$ to $\mathrm{UO}_{2}^{2+}$ in sample solution.

c. Initial volume $=40 \mathrm{ml}$. to obtain complex species $\boldsymbol{m} \boldsymbol{l} \boldsymbol{h}$ and their stability constants, $\beta_{m l h}$. The resultant species and their stability constants are summarized in Table 2. The same complex species and similar stability constants could be obtained from different titration data which were measured on the different sample solutions of $R$ values. In these calculations, $\mathrm{pH}_{\mathrm{obs}}$ and $\mathrm{pH}_{\text {calc }}$ agreed well with each other over the entire $\mathrm{pH}$ range, giving the smallest $\sigma$. As the analytical results seem to be reliable, it is concluded that two kinds of complexes, 112 and the binuclear 21-3, are formed. Their stability constants were evaluated and found to be $\log \beta_{112}=22.72$ and $\log$ $\beta_{21-3}=12.13$, respectively.

The species distribution curves for these complexes were drawn using the computer program $\mathrm{SPE}^{4}$ in accordance with the above species and their stability constants as a function of $\mathrm{pH}$; the results are given in Fig. 4. This shows that $\mathbf{1 1 2}$ is the minor species which has a limited existence in a narrow $\mathrm{pH}$ range of $2-3$, while 21-3 is the stable and main species; its formation starts at $\mathrm{pH} 2.5$, then $1 \mathrm{~mol}$ of $\mathbf{1}_{8}$ form a complex with 2 mol of $\mathrm{UO}_{2}{ }^{2+}$ almost quantitatively at $\mathrm{pH} 3.5$. The resultant complex exists in a wide $\mathrm{pH}$ range when $R$ is larger than 0.5 .

Shinkai et al. ${ }^{1}$ have reported that both $\mathbf{1}_{5}$ and $\mathbf{1}_{6}$ associate with $\mathrm{UO}_{2}^{2+}$ at a 1:1 molar ratio. Recently, we found that the $\mathrm{UO}_{2}{ }^{2+}-\mathbf{1}_{4}$ complex is at a $1: 2(\mathrm{M}: \mathrm{L})$ molar ratio. ${ }^{5}$ Thus, it can be concluded that the binding ratio of $\mathrm{UO}_{2}{ }^{2+}$ to $\mathbf{1}_{n}$ is subject to the hole size of the ligand molecule, $\mathbf{1}_{n}$.

Spectrophotometric study of $\mathbf{1}_{8}-U_{O_{2}{ }^{2+}}$ complex formation

Colorless $\mathbf{1}_{8}$ forms a red-orange complex with $\mathrm{UO}_{2}{ }^{2+}$. By using the light absorption resulting from the $\mathbf{1}_{8^{-}}$ $\mathrm{UO}_{2}{ }^{2+}$ complex, the binding ratio of $\mathbf{1}_{8}$ with $\mathrm{UO}_{2}{ }^{2+}$ was also determined by the continuous variation method at $450 \mathrm{~nm}$. The results are shown in Fig. 5. The maximum absorption is obtained at a concentration ratio of $\left[\mathrm{UO}_{2}{ }^{2+}\right] /\left(\left[\mathbf{1}_{8}\right]+\left[\mathrm{UO}_{2}{ }^{2+}\right]\right)=0.66$ in the $\mathrm{pH} 4.7$ and 7.6 solu-

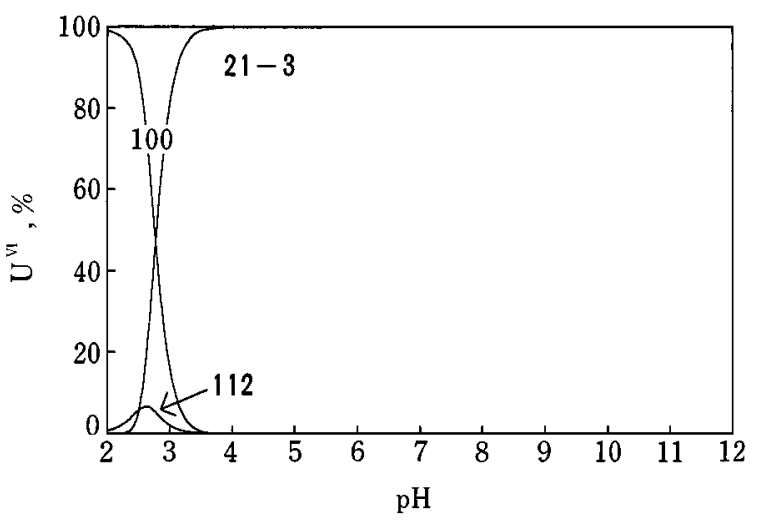

Fig. 4 Fractional diagrams of $\mathbf{1}_{8}-\mathrm{UO}_{2}{ }^{2+}$ system calculated on the basis of $\beta_{112}=22.73, \beta_{21-3}=12.13,\left[\mathrm{UO}_{2}^{2+}\right]=5.3 \mathrm{mM}$, $R=0.53$. 


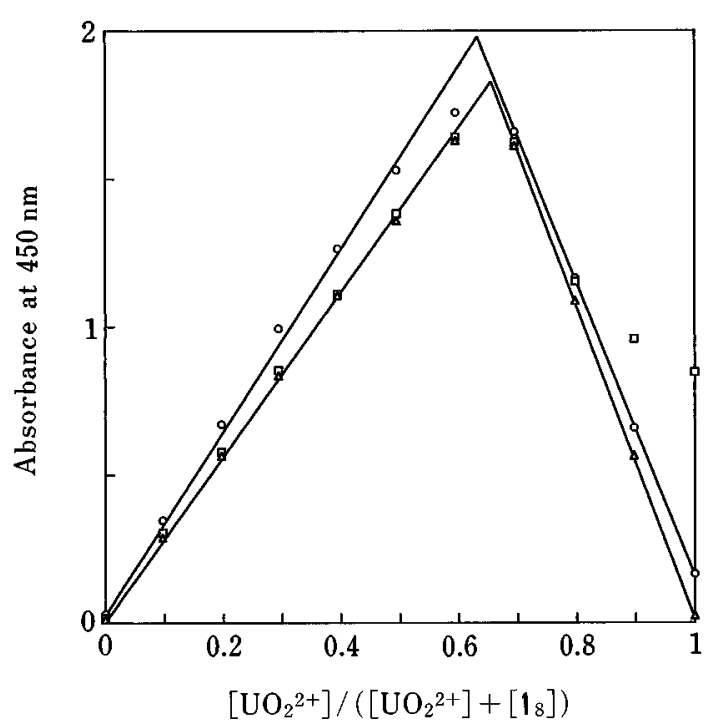

Fig. 5 Determination of the binding ratio of $\mathbf{1}_{8}-\mathrm{UO}_{2}{ }^{2+}$ by the continuous variation method at $450 \mathrm{~nm}$. Light-pass length $=1$ $\mathrm{cm} ; \mathrm{pH}: \triangle, 4.7 ; \square, 7.6 ; 0,12.1$.

tions and at 0.63 in the $\mathrm{pH} 12.1$ solution. This result indicates that the complex having $\mathrm{UO}_{2}{ }^{2+}: \mathbf{1}_{8}=2: 1$ is formed over a wide $\mathrm{pH}$ range, in agreement with the result obtained by the $\mathrm{pH}$ titration method. The absorbances at each peak of the curves are almost constant, regardless of the differences in $\mathrm{pH}$ value of the sample solution. This also indicates that $\mathbf{2 1 - 3}$ is almost completely formed even in an acidic solution at $\mathrm{pH} 4.7$. This experimental result agrees well with the result from the species distribution curve shown in Fig. 4.

At $\mathrm{pH} 2-3$, a part of $\mathbf{1}_{8}$ forms the complex with $\mathrm{UO}_{2}{ }^{2+}$ at a 1:1 molar ratio, as shown in Eq. (3) to gave 112:

$$
\mathrm{UO}_{2}{ }^{2+}+\mathrm{LH}_{4}{ }^{8-} \rightleftharpoons\left[\mathrm{UO}_{2} \mathrm{LH}_{2}\right]^{8-}+2 \mathrm{H}^{+}
$$

At $\mathrm{pH}>3.5$, the 21-3 species is formed according to Eq. (4):

$$
\left[\mathrm{UO}_{2} \mathrm{LH}_{2}\right]^{8-}+\mathrm{UO}_{2}^{2+} \rightleftharpoons\left[\left(\mathrm{UO}_{2}\right)_{2} \mathrm{LH}_{-3}\right]^{-11}+5 \mathrm{H}^{+}
$$

It has been reported ${ }^{1}$ that cyclic pentamers and cyclic hexamers act as excellent ligands for $\mathrm{UO}_{2}^{2+}$, but that cyclic tetramers do not. In addition to the above ligands, we found that the cyclic octamer, $\mathbf{1}_{8}$ can also act as an excellent ligand for $\mathrm{UO}_{2}{ }^{2+}$, forming the binuclear complex, 21-3. Although the structure of the 21-3 complex could not be established, we estimated a bistetrameric coordination arrangement of $\mathbf{1}_{8}$ with two $\mathrm{UO}_{2}{ }^{2+}$ ions. The remaining coordination site of $\mathrm{UO}_{2}{ }^{2+}$ must be combined with water and the excess protons released in Eq.(4) should be those dissociated from the coordinated water of $\mathrm{UO}_{2}{ }^{2+}$ in the complex.

Complex formation of $\mathbf{1}_{8}$ with other divalent metal ions

Figure 6 shows $\mathrm{pH}$ titration curves of $\mathbf{1}_{8}$ in the

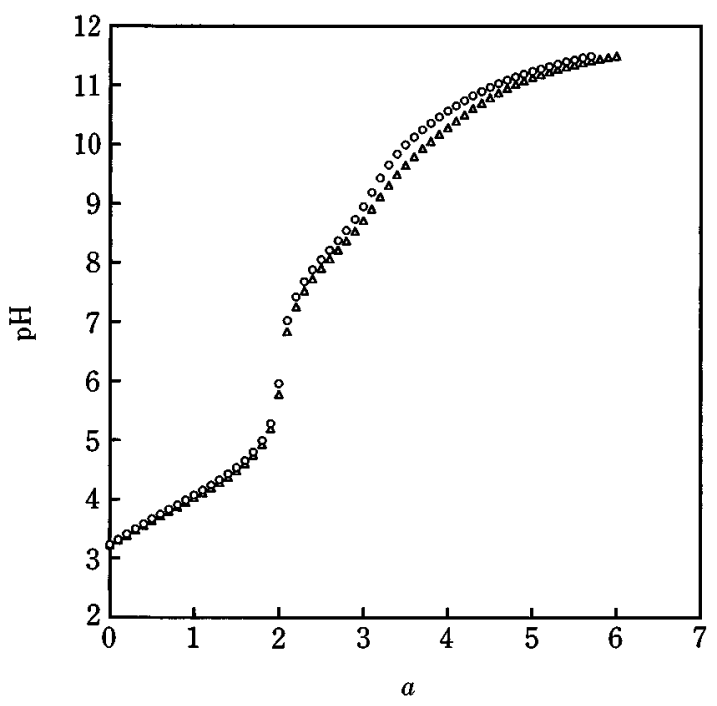

Fig. $6 \mathrm{pH}$ titration curves for $\mathbf{1}_{8}(\bigcirc, R=\infty)$ and $\mathbf{1}_{8}-\mathrm{Ca}^{2+}(\triangle$, $R=1.0$ ) mixture solutions with $0.1 \mathrm{M} \mathrm{KOH}$ at $25^{\circ} \mathrm{C}$. $\mu=0.1$ with $\mathrm{KNO}_{3}$. Initial volume of sample solution= $40 \mathrm{ml}$.

Table $3 \quad \mathbf{1}_{8}-\mathrm{M}^{2+}$ species and their stability constants, $\log \beta_{m l h^{\mathrm{a}}}$ at $25^{\circ} \mathrm{C}$

\begin{tabular}{llllllll}
\hline & \multicolumn{2}{c}{ Amount of $\mathrm{M}^{2+}$ and $\mathbf{1}_{8} / \mathrm{mmol}^{\mathrm{c}}$} & & \multicolumn{4}{c}{$\log \beta_{\text {mlh }}$} \\
\cline { 2 - 3 } \cline { 5 - 7 } & \multicolumn{1}{c}{$\mathrm{M}^{2+}$} & $\mathbf{1}_{8}$ & $\mathbf{1 1 2}$ & $\mathbf{1 1 1}$ & $\mathbf{1 1 0}$ & $\mathbf{1 1 - 1}$ \\
\hline 1.2 & $\mathrm{Mg} 0.0520$ & 0.0648 & - & 11.92 & 3.39 & -8.31 \\
0.51 & $\mathrm{Ca} 0.216$ & 0.110 & 20.1 & 12.5 & 3.4 & - \\
1.0 & $\mathrm{Ca} 0.108$ & 0.110 & 20.1 & 12.6 & 3.4 & - \\
1.2 & $\mathrm{Ca} 0.0540$ & 0.0648 & 20.6 & 12.9 & 3.7 & - \\
1.2 & $\mathrm{Co} 0.0558$ & 0.0648 & 20.4 & 12.9 & - & - \\
1.3 & $\mathrm{Mn} 0.0495$ & 0.0648 & 20.7 & 13.4 & - & - \\
1.2 & $\mathrm{Ni} 0.0552$ & 0.0648 & 20.1 & 12.7 & - & - \\
1.2 & $\mathrm{Zn} 0.0531$ & 0.0648 & 20.3 & 13.4 & - & - \\
\hline
\end{tabular}

a. $\mu=0.1$ with $\mathrm{KNO}_{3}$.

b. $R=$ molar ratio of $\mathbf{1}_{8}$ to $\mathrm{M}^{2+}$ in sample solution.

c. Initial volume $=40 \mathrm{ml}$.

absence $(R=\infty)$ and presence of $\mathrm{Ca}^{2+}(R=1)$. Both curves have similar $\mathrm{pH}$ values to each other at each titration point. This indicates that the degree of complex formation between $\mathbf{1}_{8}$ and $\mathrm{Ca}^{2+}$ is very weak. Similar $\mathrm{pH}$ titration curves were also obtained for other divalent metal ions such as $\mathrm{Mg}^{2+}, \mathrm{Co}^{2+}, \mathrm{Mn}^{2+}, \mathrm{Ni}^{2+}$, and $\mathrm{Zn}^{2+}$. Table 3 shows the complex species and the stability constants computed for these divalent metal ions. Three kinds of 1:1 species, i.e., 112, 111, and $\mathbf{1 1 0}$ were formed for $\mathrm{Ca}^{2+}$, while the last two species, 111 and 110, were formed for $\mathrm{Mg}^{2+}$ in addition to 11-1. The formations of the first two species, 112 and 111, were found for other divalent metal ions. These metal complexes have stabilities similar to each other. Figure 7 shows species distribution curves for $\mathrm{Mg}^{2+}$ complex as a function of $\mathrm{pH}$. At $\mathrm{pH}<8$, almost all $\mathrm{Mg}^{2+}$ is uncomplexed. This means that these divalent metal ions do 


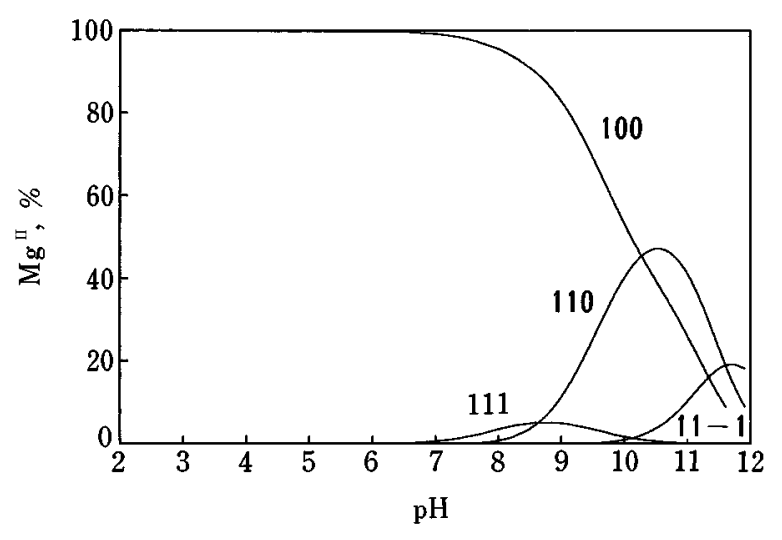

Fig. 7 Fractional diagrams of $\mathbf{1}_{8}-\mathrm{Mg}^{2+}$ system calculated on the basis of $\beta_{111}=11.9_{2}, \beta_{110}=3.2_{9}, \beta_{11-1}=-8.3_{1},\left[\mathrm{Mg}^{2+}\right]=1.3$ $\mathrm{mM}, R=1.25$.

not form stable complexes with $\mathbf{1}_{8}$. Thus in the acidic solution no complex is formed; divalent metal ions are present as uncomplexed metal ions.

Furthermore, the facts that the $\mathrm{pH}$ titration curve of a $\mathbf{1}_{8}-\mathrm{Cu}^{2+}$ mixture $(R=1)$ solution overlapped completely with that for $\mathbf{1}_{8}$ alone $(R=\infty)$ up to $a=2$ and also that copper hydroxide was produced at $a>2$ indicate that no copper complex was formed at all with $\mathbf{1}_{8}$.

\section{Selective reactivity of $\mathbf{1}_{8}$ for $\mathrm{UO}_{2}{ }^{2+}$}

As discussed above, $\mathbf{1}_{8}$ can form a stable complex only with $\mathrm{UO}_{2}{ }^{2+}$; some other divalent metal ions form extremely unstable complexes and $\mathrm{Cu}^{2+}$ does not form any $\mathbf{1}_{8}$-complex. The concentrations of trivalent metal ions in seawater are lower by far than those of divalent metal ions. Thus when studying the complex formation of metal ions with $\mathbf{1}_{8}$ in seawater, we can exclude the presence of trivalent metal ion complexes. Among the divalent metal ions, $\mathrm{Mg}^{2+}$ is the highest in concentration; thus the selective reactivity of $\mathrm{UO}_{2}{ }^{2+}$ to $\mathrm{Mg}^{2+}$, $\mathrm{Sr}\left(\mathrm{UO}_{2} / \mathrm{Mg}\right)$, was calculated as the concentration ratio of these metal ions complexed with $\mathbf{1}_{8}$.

As indicated in the present study, $\mathbf{1}_{8}$ forms 21-3 species with $\mathrm{UO}_{2}{ }^{2+}$ at $\mathrm{pH} 8.0$, and its overall stability constant, $\beta_{21-3}\left(\mathrm{UO}_{2}\right)$ is given by Eq. (5):

$$
\begin{aligned}
{\left[\left(\mathrm{UO}_{2}\right)_{2} \mathrm{LH}_{-3}\right] /\left[\mathrm{UO}_{2}{ }^{2+}\right]^{2}[\mathrm{~L}]\left[\mathrm{H}^{-3}\right.} & = \\
\beta_{21-3}\left(\mathrm{UO}_{2}\right) & =10^{12.13}
\end{aligned}
$$

On the other hand, $\mathrm{Mg}^{2+}$ forms only $\mathbf{1 1 1}$ species at $\mathrm{pH}$ 8.0 and its overall stability constant, $\beta_{111}(\mathrm{Mg})$, is given by Eq. (6):

$$
[\mathrm{MgLH}] /\left[\mathrm{Mg}^{2+}\right][\mathrm{L}][\mathrm{H}]=\beta_{111}(\mathrm{Mg})=10^{11.92}
$$

From Eqs. (5) and (6), we obtain Eq. (7):

$$
\begin{aligned}
& \mathrm{Sr}\left(\mathrm{UO}_{2} / \mathrm{Mg}\right)=\left[\left(\mathrm{UO}_{2}\right)_{2} \mathrm{LH}_{-3}\right] /[\mathrm{MgLH}]= \\
& \quad \beta_{21-3}\left(\mathrm{UO}_{2}\right) / \beta_{111}(\mathrm{Mg}) \cdot\left[\mathrm{UO}_{2}^{2+}\right]^{2} \cdot\left[\mathrm{Mg}^{2+}\right]^{-1} \cdot\left[\mathrm{H}^{+}\right]^{-4}
\end{aligned}
$$

The selective reactivity, $\operatorname{Sr}\left(\mathrm{UO}_{2} / \mathrm{Mg}\right)$, i.e., the concen- tration ratio of $\mathrm{UO}_{2}{ }^{2+}$ to $\mathrm{Mg}^{2+}$ in the $\mathbf{1}_{8}$-complexes, $\left[\left(\mathrm{UO}_{2}\right)_{2} \mathrm{LH}_{-3}\right] /[\mathrm{MgLH}]$, is a function of $\mathrm{pH}, \mathrm{UO}_{2}{ }^{2+}$ and $\mathrm{Mg}^{2+}$ concentrations in seawater. These are already known to be $\left[\mathrm{UO}_{2}{ }^{2+}\right]=1.5 \times 10^{-8} \mathrm{M},\left[\mathrm{Mg}^{2+}\right]=5.2 \times 10^{-2} \mathrm{M}$, and $\left[\mathrm{H}^{+}\right]=1.0 \times 10^{-8} \mathrm{M}$, respectively. Thus the value we obtained for $\operatorname{Sr}\left(\mathrm{UO}_{2} / \mathrm{Mg}\right)$ was $7.0 \times 10^{17}$.

It has been reported ${ }^{1}$ that $\mathbf{1}_{6}$ has a high selective reactivity with $\mathrm{UO}_{2}{ }^{2+}$ and its $\mathrm{UO}_{2}{ }^{2+}$ selectivity factor for other divalent metal ions, $\mathrm{Sf}\left(\mathrm{UO}_{2} / \mathrm{M}^{2+}\right)$ was $10^{11-17}$, where $\mathrm{Sf}\left(\mathrm{UO}_{2} / \mathrm{M}^{2+}\right)$ was the ratio of the association constants of $\mathrm{UO}_{2}{ }^{2+}$ to that of $\mathrm{M}^{2+}, \mathrm{K}_{16-\mathrm{UO} 2} / \mathrm{K}_{16-\mathrm{M} 2+}$. The value for selective reactivity, $\operatorname{Sr}\left(\mathrm{UO}_{2} / \mathrm{Mg}\right)$, in the present study happened to agree with the value for this selectivity factor, although there is no relation between these two selectivities. Furthermore the ratio of overall stability constants for these complexes, $\beta_{21-3}\left(\mathrm{UO}_{2}\right) /$ $\beta_{111}(\mathrm{Mg})$, is meaningless in the present study. The value for the selective reactivity of $\mathrm{UO}_{2}{ }^{2+}$ to $\mathrm{Cu}^{2+}$, $\mathrm{Sr}\left(\mathrm{UO}_{2} / \mathrm{Cu}\right)$, will be infinite because $\mathrm{Cu}^{2+}$ does not form any complex with $\mathbf{1}_{8}$.

The concentration factor of $\mathrm{UO}_{2}^{2+}$ to $\mathrm{Mg}^{2+}$ with $\mathbf{1}_{8}$, the factor defined as $\left(\left[\mathrm{UO}_{2} \mathrm{LH}_{-3}\right] /\left[\mathrm{UO}_{2}\right]\right) /([\mathrm{MgLH}] /[\mathrm{Mg}])$, is also a function of $\mathrm{pH}$ and concentration of $\mathrm{UO}_{2}{ }^{2+}$. This value was calculated as indicated in Eq. (8) and found to be $2.0 \times 10^{24}$.

$$
\begin{aligned}
\left(\left[\mathrm{UO}_{2} \mathrm{LH}_{-3}\right] /\left[\mathrm{UO}_{2}\right]\right) /([\mathrm{MgLH}] /[\mathrm{Mg}]) & = \\
10^{0.21}\left[\mathrm{UO}_{2}^{2+}\right]\left[\mathrm{H}^{+}\right]^{-4} & =2.0 \times 10^{24}
\end{aligned}
$$

Since the stabilities of a series of $\mathbf{1}_{8}-\mathrm{M}^{2+}$ complexes were found to be similar to those of $\mathrm{Mg}^{2+}$ complexes and the concentrations of divalent metal ions in seawater are lower by far than that of $\mathrm{Mg}^{2+}$, we can conclude that $\mathbf{1}_{8}$ essentially only forms the complex with $\mathrm{UO}_{2}{ }^{2+}$ in seawater.

\section{Effect of carbonate ion}

Since, almost all $\mathrm{UO}_{2}{ }^{2+}$ in seawater is present in the form of the bicarbonate complex, $\mathrm{UO}_{2}\left(\mathrm{CO}_{3}\right)_{2}{ }^{2-}$, due to the presence of carbonate ion, we studied the influence of carbonate ion on the formation of a $\mathbf{1}_{8}-\mathrm{UO}_{2}{ }^{2+}$ complex.

The sample solutions were prepared by adding a given amount of $\mathbf{1}_{8}$ to the sodium carbonate solutions containing a given amount of $\mathrm{UO}_{2}^{2+}$, where the carbonate- $\mathrm{UO}_{2}{ }^{2+}$ solutions were left beforehand for $24 \mathrm{~h}$ to complete the formation of bicarbonate- $\mathrm{UO}_{2}{ }^{2+}$ complex, $\mathrm{UO}_{2}\left(\mathrm{CO}_{3}\right)_{2}{ }^{2-}$. Then, the visible absorption spectra of the sample solutions were measured at given time intervals at $25^{\circ} \mathrm{C}$. Identical absorption spectra were recorded for each solution having various amounts of carbonate ion with constant amounts of $\mathbf{1}_{8}$ and $\mathrm{UO}_{2}{ }^{2+}$ and including a carbonate-free solution. The $\mathrm{pH}$ value of the solutions was kept at 8.0 by using $0.01 \mathrm{M} 2-[4-(2-$ hydroxyethyl)-1-piperazinyl]ethanesulfonic acid (HEPES)(Dojin Chemical Co., Japan). The absorbances at $450 \mathrm{~nm}$ measured after $24 \mathrm{~h}$ are given in Fig. 8 as a function of the carbonate concentration at $\mathrm{pH}$ 8.0. This figure indicates that no influence on the sta- 


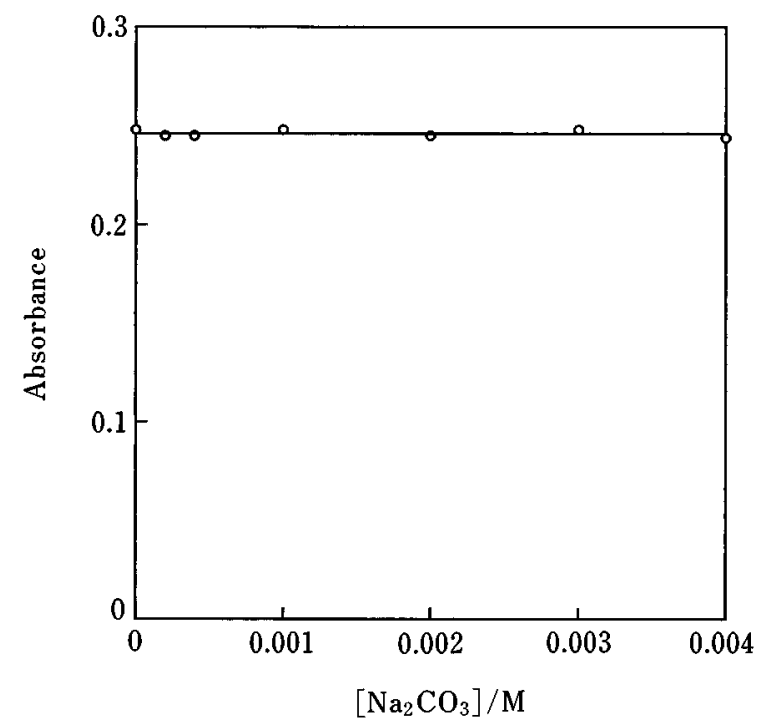

Fig. 8 Influence of carbonate ion concentration on the absorbance of $\mathbf{1}_{8}-\mathrm{UO}_{2}{ }^{2+}$ complex at $25^{\circ} \mathrm{C}$. $\quad\left[\mathrm{UO}_{2}\left(\mathrm{NO}_{3}\right)_{2}\right]=$ $2.00 \times 10^{-4} \mathrm{M},\left[\mathbf{1}_{8}\right]=1.05 \times 10^{-4} \mathrm{M}, \mathrm{pH}=8.0$ with $[$ HEPES $]=0.01$ $\mathrm{M}$, reaction time $=24 \mathrm{~h}$, wavelength $=450 \mathrm{~nm}$, light-pass length $=1 \mathrm{~cm}$, reference $=$ water.

bility of $\mathbf{1}_{8}-\mathrm{UO}_{2}{ }^{2+}$ complex can be observed up to $4 \times 10^{-3} \mathrm{M}$. When carbonate concentration is smaller than $3 \times 10^{-3} \mathrm{M}$, the absorbances reached values almost identical to those in Fig. 8 at least in $1 \mathrm{~h}$. In the $4 \times 10^{-3}$ M solution, the absorbances were about $95 \%$ of those given in Fig. 8. This means the presence of a large amount of carbonate ion only decreases the rate of the complex formation reaction between $\mathbf{1}_{8}$ and $\mathrm{UO}_{2}{ }^{2+}$ to a greater or lesser degree.

The present study indicates that $\mathbf{1}_{8}$ is also a selective uranophile equal to or higher in efficiency than $\mathbf{1}_{6}, \mathbf{1}_{5}$, and their hexacarboxylate derivatives ${ }^{1}$ and also indicates its possible use as functional group of an adsorbent for the selective extract of $\mathrm{UO}_{2}{ }^{2+}$ from seawater. ${ }^{6}$

\section{References}

1. S. Shinkai, H. Koreishi, K. Ueda, T. Arimura and O. Manabe, J. Am. Chem. Soc., 109, 6371 (1987).

2. I. Yoshida, N. Yamamoto, F. Sagara, D. Ishii, K. Ueno and S. Shinkai, Bull. Chem. Soc. Jpn., 65, 1012 (1992).

3. G. Arena, R. Cali, G. Guiseppelomarko, E. Rizzarelli, D. Sciotto, R. Ungaro and R. Casnati, Supramolecular Chem., 1, 19 (1992).

4. A. E. Martell and R. J. Motekaitis, "The Determination and Use of Stability Constants", VCH Publishers, New York, 1988.

5. K. Hayashi, Kumamoto Institute of Technology Master's Thesis, 1995

6. S. Shinkai, Y. Shiramama, H. Satoh and O. Manabe, J. Chem. Soc. Perkin Trans, II, 1989, 1167.

(Received December 1, 1997) (Accepted February 16, 1998) 